\title{
KESILAPAN PENGURANGAN DALAM PEMEROLEHAN GENDER GRAMATIKAL BAHASA PERANCIS
}

\section{OMISSION ERRORS IN FRENCH GRAMMATICAL GENDER ACQUISITION}

\author{
Hazlina Abdul Halim¹, Normaliza Abdul Rahim \& \\ Roslina Mamat \\ Fakulti Bahasa Moden dan Komunikasi \\ Universiti Putra Malaysia
}

${ }^{1}$ Corresponding author: nina@fbmk.upm.edu.my

\begin{abstract}
ABSTRAK
Tujuan - Kajian ini bertujuan menganalisis kesilapan pengurangan oleh pelajar yang mempelajari kemahiran bahasa Perancis sebagai bahasa asing.

Metodologi - Kajian ini menggunakan kaedah penganalisisan kualitatif dan kuantitatif. Seramai 60 responden terlibat dalam kajian ini, di mana mereka diminta membuat pembetulan yang perlu pada 20 ayat bahasa Perancis yang bergender gramatikal dan melakukan satu aktiviti penulisan dalam 10-15 ayat selepas 100 jam pembelajaran kemahiran bahasa Perancis.

Dapatan - Hasil kajian mendapati bahawa pelajar melakukan kesilapan pengurangan terhadap kata sifat, artikel, kata sendi dan kata posesif dalam pembetulan ayat dan pembentukan ayat bahasa Perancis.

Kepentingan - Kajian ini memberikan implikasi pedagogi kepada pengajar bahasa Perancis tentang perspektif yang berbeza terhadap implementasi pengajaran gender kepada pelajar. Dapatan kajian diharapkan dapat memberikan gambaran bagaimana proses pengajaran dan pembelajaran dapat dipertingkatkan, dan pendedahan kepada kesilapan pengurangan membuka jalan untuk menilai semula metodologi pengajaran, penyediaan modul dan penyampaian untuk mempertingkatkan kemajuan pelajar dan prestasi pengajaran guru.
\end{abstract}

Kata kunci: Kesilapan pengurangan, bahasa Perancis, aktiviti penulisan, ayat bahasa Perancis 


\section{ABSTRACT}

Purpose - The objective of this study was to analyse the omission errors in French by students of a French language proficiency course.

Method - This study utilised both quantitative and qualitative methods of data analysis. The respondents consisted of 60 students who were asked to do necessary changes to French sentences with grammatical gender and to develop a writing task after 100-hours of French learning.

Findings - The result of the study indicate that the respondents made omission errors to adjectives, articles, prepositions and possessive nouns when they corrected the sentences and when making sentences in French.

Significance - The study has pedagocical complications on French language instruction, particularly with regard to implementing the teaching of grammatical gender. It is hoped that the findings can provide a better picture on how learning and teaching can be improved. Exposure to omission errors will help teachers enhance the quality of teaching through reexamining teaching methods, materials and delivery.

Keywords: Omission errors, French language, writing activity, French sentences

\section{PENGENALAN}

Bahasa merupakan alat komunikasi yang utama bagi manusia. Namun, kekangan bahasa timbul apabila lebih daripada satu bahasa digunakan untuk berkomunikasi, sama ada dalam bentuk lisan ataupun tulisan. Hal ini kerana setiap satu bahasa itu berbeza daripada yang lain dalam pelbagai bentuk. Perbezaan ini boleh berlaku secara nyata (sebutan dan perbendaharaan kata) atau secara tidak nyata (tatabahasa). Sesuatu ayat yang ringkas boleh menjadi ayat yang kompleks sekiranya dinyatakan dalam bahasa yang berbeza. Oleh yang demikian, penutur daripada bahasa yang berlainan seharusnya mengadaptasi aspek yang berlainan dalam 
dunia ini untuk menggunakan bahasa mereka dengan cara yang betul dan sempurna. Menurut Slobin (1996:70):

\section{"It appears that speakers of different languages have to attend to and encode strikingly different aspects of the world in order to use their language properly"...}

Perbezaan yang disebutkan di atas jelas menunjukkan betapa pentingnya pembelajaran bahasa kedua. Bahasa Perancis misalnya, digunakan sebagai alat untuk berkomunikasi secara lisan dan tulisan dan salah satu aspek yang penting dalam bahasa Perancis adalah tatabahasanya (Hazlina \& Mohd Azidan, 2011c). Walaupun sedikit kesilapan dilakukan, ia boleh membawa kepada pengertian berbeza dan ketidakfahaman tentang apa yang cuba disampaikan.

\section{SOROTAN KAJIAN}

Dalam pada seseorang itu mempelajari bahasa kedua (B2), beliau akan melakukan kesalahan dan kesilapan yang dianggap sebagai sebahagian dari satu proses pembelajaran. Dulay, Burt dan Krashen (1982) menyatakan bahawa sebahagian besar kesilapan yang dilakukan oleh mereka yang mempelajari B2 adalah lebih khusus kepada bahasa itu sendiri daripada berpunca daripada gangguan daripada bahasa ibunda. Corder (1981) menyatakan kesilapan adalah suatu elemen yang penting sebagai bukti untuk mengukur pengetahuan dan kemahiran bahasa seseorang. Pengajaran bahasa akan menjadi lebih berkesan jika pengajar tahu bahawa strategi pembelajaran yang digunakan oleh pelajar boleh membantu proses pengajaran bahasa tersebut :

... “The paradigm shift in linguistics from a
behaviouristic view of language to a more rationalistic
view and claims that in language teaching one
noticeable effect is to shift the emphasis away from
'teaching' towards a study of 'learning'”... (Corder,
1967: pp. 161-167)

Menurut Clark (1985), "kesilapan” merupakan istilah yang digunakan secara rawak dalam "analisis yang mendapati satu 
perbezaan”. Kesilapan juga merupakan kesan daripada kesemua faktor luaran selain daripada yang apa yang dirumuskan secara khusus dalam sesuatu analisis seperti faktor motivasi, latar belakang pendidikan pelajar dan sebagainya. James (1998) pula menyifatkan sesuatu kesilapan yang dilakukan oleh seseorang pelajar menggambarkan tahap pengetahuan yang ada pada pelajar tersebut jika ianya tidak boleh diperbaiki dengan cara automatik oleh pelajar tersebut. Beliau menekankan bahawa kesilapan hanya boleh diperbetulkan jika suatu input yang relevan diberikan dalam proses pembelajaran itu diterima oleh pelajar.

Oleh yang demikian, analisis kesilapan adalah suatu pendekatan dalam mengenal pasti dan membezakan masalah yang dihadapi dalam sesuatu pembelajaran. Analisis ini memerlukan pengumpulan kesilapan yang sistematik, yang dianalisis dan dikelaskan dengan tujuan untuk memahami kesukaran sesuatu pembelajaran.

Salah satu cabang tatabahasa yang paling rumit untuk pelajar bahasa Perancis merupakan gender gramatikal. Menurut Trask (1998, p. 93), gender gramatikal adalah sebagai satu fenomena yang terdapat dalam sesetengah bahasa, di mana kata nama dalam bahasa tersebut dibahagikan kepada dua pengkelasan atau lebih, dan memerlukan penyesuaian ke atas perkataaan lain yang berkaitan secara gramatikal dengannya: contohnya preposisi, kata kerja dan kata sifat. Corbett (1991, p.1) pula menyatakan :

“ To understand what linguists mean by 'gender', a good starting point is Hockett's definition: 'Genders are classes of nouns reflected in the behavior of associated words' (1958, p.231). A language may have two or more such classes of genders"...

Menurut Surridge (1996), gender gramatikal dalam bahasa Perancis merupakan sesuatu pelengkap kepada kata nama. Oleh yang demikian, penutur asli bahasa Perancis tidak akan bertoleransi terhadap sebarang kesalahan gender yang dilakukan. Menyedari kepentingan inilah, pengkaji cuba meneroka kesalahan gender gramatikal yang dilakukan oleh pelajar melalui pendekatan analisis kesilapan supaya ianya dapat digunakan untuk memperbaiki mutu pembelajaran bahasa Perancis. Menurut Kitao \& Kitao (2000), penggunaan analisis kesilapan dalam pembelajaran bahasa dapat 
membantu pengajar meramalkan jenis-jenis kesilapan yang bakal dilakukan oleh pelajar, dengan ini berguna dalam penyediaan bahan pengajaran dan cara penyampaian pengajar tersebut.

Analisis kesilapan adalah salah satu cabang linguistik terapan yang penting dalam proses pembelajaran bahasa kedua. Aini Karim (2007) menyatakan, pendekatan analisis kesilapan bahasa merupakan satu teknik yang digunakan untuk mengukur kemajuan bahasa pelajar dalam sesuatu bahasa, dengan mencatat dan mengkelaskan kesalahan yang dilakukan oleh individu atau berkumpulan. Ellis (1994:701) mendefinisikan analisis kesilapan bahasa sebagai

“... a set of procedures for identifying, describing and explaining errors in learner language."

Analisis kesilapan bahasa ini wujud disebabkan beberapa faktor. Antaranya adalah kesedaran yang wujud dalam kalangan ahli linguistik tentang kelemahan hipotesis analisis kontrastif. Menurut Sridhar (1981), walaupun pada peringkat awal, analisis kontrastif secara relatif menggunakan peralatan linguistik yang canggih dan tuntutan yang kuat untuk meramal kebanyakan kesalahan dalam pembelajaran bahasa sasaran, seperti yang didakwa oleh penyokong analisis kontrastif seperti Fries (1945) dan Lado (1957). Namun didapati analisis kontrastif tidak dapat menjelaskan banyak kesalahan selain kesalahan daripada gangguan bahasa ibunda.

Kasper dan Kellerman (1997, p. 1-13) pula menyatakan bahawa kesilapan pengurangan (omission error) dilakukan oleh seseorang pada awal tahap pembelajarannya yang cenderung meninggalkan perkataan berfungsi (function words) berbanding dengan perkataan yang membawa maksud (content words).

... "Learners in the early stages of learning tend to omit function words rather than content words. More advanced learners tend to be aware of their ignorance of content words and rather than omit one"...

Kajian Lee (2009) yang melibatkan korpus kesilapan partikel dalam bahasa Korea mendapati kesilapan pengurangan partikel adalah kesilapan yang paling kerap dilakukan oleh pelajar bahasa Korea untuk kebanyakan tahap kemahiran bahasa. Menurut Lee, 
Jang \& Seo (2009), kesilapan partikel yang terlampau kerap akan menyebabkan komunikasi seseorang tidak dapat difahami, tidak natural dan seperti percakapan seorang bayi.

Menurut Yarmohammadi (2002), kesilapan dalam penulisan seseorang pelajar mungkin berpunca daripada pengaruh bahasa ibunda. Pendapat ini disokong oleh Hazlina et al., (2011c) yang mendapati kesilapan pengurangan, seperti kesilapan yang lain, adalah berpunca dari pengaruh bahasa dominan pelajar, iaitu bahasa Melayu dan bahasa Inggeris. Pengaruh ini menyebabkan pengguguran elemen tatabahasa seperti artikel oleh pelajar yang menjadi punca kesilapan pengurangan ini dilakukan.

Daripada dapatan sarjana linguistik di atas, dapat kita rumuskan bahawa kesilapan tatabahasa dalam pembelajaran adalah satu fenomena rentas bahasa, yang mencetuskan masalah dari segi tatabahasa, maksud mahupun pemahaman tentang bahasa tersebut. Dengan mengambil kira gender gramatikal merupakan salah satu cabang tatabahasa bahasa Perancis yang paling rumit, pengkaji mengambil inisiatif untuk merungkaikan kesilapan pengurangan yang mungkin dilakukan oleh pelajar bahasa tersebut.

Untuk kajian ini, pengkaji menyifatkan kesilapan pengurangan sebagai kesilapan meninggalkan atau tidak memberi atribusi sesuatu elemen bergender gramatikal yang dikaitkan dengan kata nama yang digunakan. Contoh kesilapan akan dihuraikan seterusnya dengan menggunakan simbol $\leq>$ untuk menandakan ketiadaan artikel.

\section{OBJEKTIF KAJIAN}

Objektif kajian ini adalah untuk mengenal pasti dan membincangkan kesilapan pengurangan oleh pelajar UPM dalam mengaplikasikan gender gramatikal dalam penulisan bahasa Perancis sebagai bahasa asing oleh mereka.

\section{KEPENTINGAN KAJIAN}

Hasil kajian ini adalah penting dalam mengupas isu pembelajaran gender gramatikal, untuk kita dapat memahami di manakah masalah tatabahasa ini timbul, dan bagaimana gender gramatikal ini diolah 
oleh seseorang pelajar yang mempelajari bahasa Perancis ini. Dapatan daripada kajian yang dijalankan seterusnya akan berupaya membantu para pengajar untuk menyusun rancangan pengajaran, penyediaan kaedah dan strategi pembelajaran yang boleh digunakan untuk memperbaiki prestasi pemahaman dan penguasaan gender gramatikal dalam kalangan pelajar.

Pengkaji juga berharap agar dengan adanya kajian ini, ianya dapat mewujudkan corak pembelajaran bahasa Perancis yang lebih berkesan dan yang dipercayai akan dapat membantu para pelajar untuk menguasai bahasa Perancis dengan lebih mantap. Seterusnya, adalah diharapkan kajian ini akan membantu pihak universiti dan pihak lain untuk meningkatkan mutu pembelajaran pelajar dengan mengenal pasti keperluan dan penekanan yang perlu diketengahkan dalam pembelajaran gender dalam bahasa.

\section{BATASAN KAJIAN}

Dalam kajian ini, pengkaji hanya menganalisis kesilapan yang dilakukan dengan merujuk kepada bahasa dominan dalam pembelajaran responden di universiti, iaitu bahasa Melayu dan bahasa Inggeris. Pengkaji juga tidak mengambil kira jenis kesilapan lain yang mungkin terdapat dalam ayat yang dibina oleh responden.

\section{INSTRUMEN KAJIAN}

Sampel kajian ini terdiri daripada pelajar elektif bahasa Perancis tahap 2 berbangsa Melayu, Cina dan India yang berumur antara 19 hingga 23 tahun. Jumlah responden adalah seramai 60 orang iaitu 48 pelajar Cina, 9 pelajar Melayu dan 3 pelajar India. Responden mempunyai latar belakang bahasa yang sama, iaitu bahasa Melayu dan bahasa Inggeris, di samping sesetengah daripada mereka mempunyai bahasa pertamanya seperti bahasa Tamil dan bahasa Cina. Dalam kajian ini, pengkaji membuat analisis hanya dengan mengambil kira bahasa Inggeris dan bahasa Melayu, iaitu bahasa dominan responden dalam pembelajaran mereka secara formal semasa di universiti. Walau bagaimanapun, daripada kutipan data bahagian demografi soal selidik, 90\% daripada responden 
menyatakan bahasa dominan yang digunakan dalam pembelajaran mereka, dan pemprosesan informasi dalam pemerolehan bahasa Perancis adalah bahasa Inggeris.

Instrumen untuk kajian ini adalah kertas soalan ayat-ayat bergender dan aktiviti penulisan. Untuk kertas soalan, ia digubal adalah berdasarkan perkataan dan ayat yang dipelajari sepanjang pembelajaran bahasa Perancis responden. Sebanyak 20 ayat telah disediakan. Responden dikehendaki menganalisis ayat tersebut dan menyatakan sama ada ia betul dari segi gender gramatikalnya ataupun tidak, dan membuat pembetulan bila perlu. Kesemua ayat yang diberikan telah dipelajari oleh responden perbendaharaan kata dan penstrukturannya. Daripada 20 ayat tersebut, 10 ayat telah diubah supaya mempunyai kesilapan gender yang perlu diperbetulkan oleh responden. Ayat yang sepatutnya tidak diperbetulkan oleh responden (kerana tiada kesilapan atribusi gender) adalah seperti berikut:

Jadual 1

Senarai Ayat Tanpa Pembetulan di Kertas Soalan

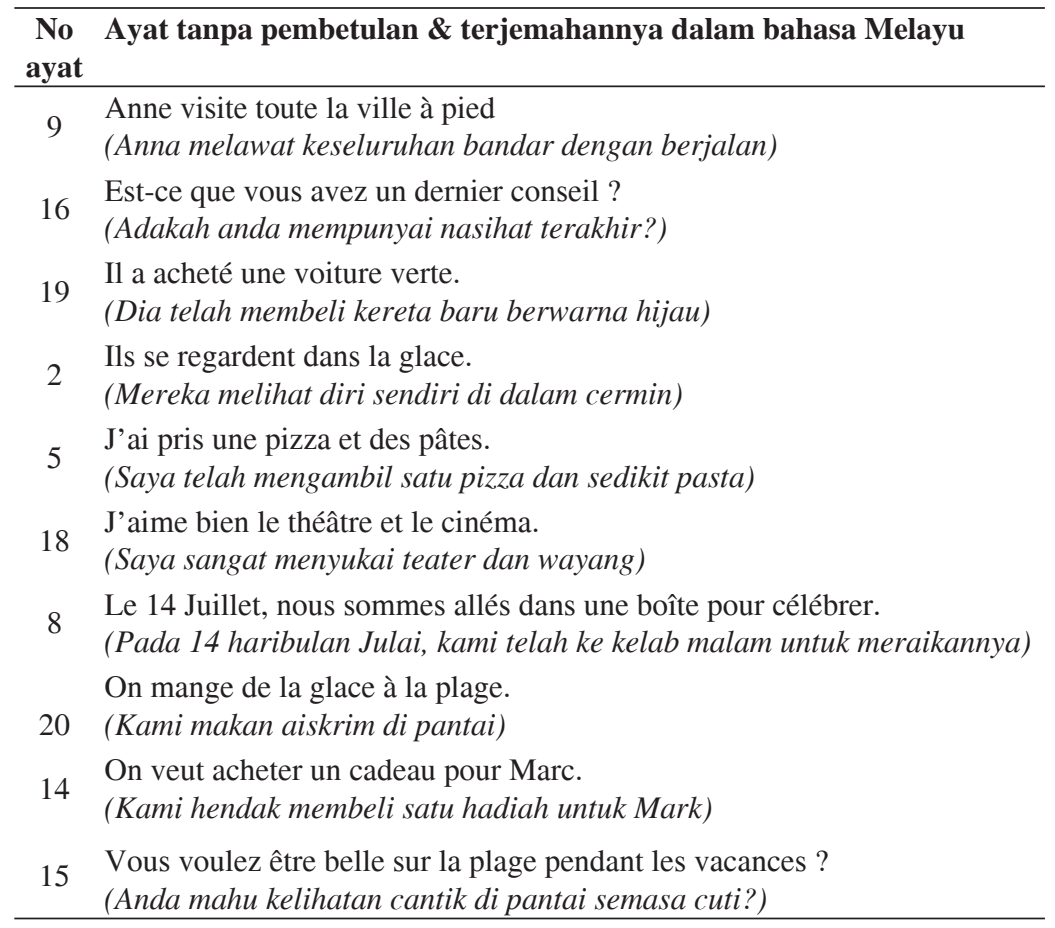


Ayat tanpa kesilapan atribusi gender pula mempunyai gender gramatikal yang dikaitkan dengan artikel kata sifat dan kata pertanyaan. Ayat tersebut adalah seperti berikut:

\section{Jadual 2}

Senarai Ayat dengan Pembetulan di Kertas Soalan

\begin{tabular}{|c|c|c|}
\hline $\begin{array}{l}\text { No. } \\
\text { ayat }\end{array}$ & $\begin{array}{l}\text { Ayat dengan kesilapan gender \& } \\
\text { terjemahan dalam bahasa Melayu } \\
\text { (kesilapan dihitamkan) }\end{array}$ & $\begin{array}{l}\text { Pembetulan ayat \& kategori } \\
\text { pembetulan } \\
\text { (pembetulan dihitamkan) }\end{array}$ \\
\hline 3 & $\begin{array}{l}\text { Ces chaussures sont jolis, non? } \\
\text { (Kasut ini cantik kan?) }\end{array}$ & $\begin{array}{l}\text { Ces chaussures sont jolies, non? } \\
\text { (pembetulan kata sifat) }\end{array}$ \\
\hline 10 & $\begin{array}{l}\text { Cette année, nous célébrons notre } \\
\text { anniversaire sur une bateau. } \\
\text { (Tahun ini, kami meraikan hari } \\
\text { ulang tahun kami di atas sebuah } \\
\text { kapal) }\end{array}$ & $\begin{array}{l}\text { Cette année, nous célébrons notre } \\
\text { anniversaire sur un bateau. } \\
\text { (pembetulan artikel) }\end{array}$ \\
\hline 7 & $\begin{array}{l}\text { Etienne et moi avons passé un } \\
\text { excellent soirée. } \\
\text { (Etienne dan saya telah melalui satu } \\
\text { malam yang sangat baik) }\end{array}$ & $\begin{array}{l}\text { Etienne et moi avons passé une } \\
\text { excellente soirée. } \\
\text { (pembetulan kata sifat \& artikel) }\end{array}$ \\
\hline 1 & $\begin{array}{l}\text { J'achète un bouteille de coca. } \\
\text { (Saya membeli satu botol coke) }\end{array}$ & $\begin{array}{l}\text { J'achète une bouteille de coca. } \\
\text { (pembetulan artikel) }\end{array}$ \\
\hline 12 & $\begin{array}{l}\text { Je trouve une billet de } 5 \text { Ringgit. } \\
\text { (Saya menjumpai sekeping nota } 5 \\
\text { Ringgit) }\end{array}$ & $\begin{array}{l}\text { Je trouve un billet de } 5 \text { Ringgit. } \\
\text { (pembetulan artikel) }\end{array}$ \\
\hline 4 & $\begin{array}{l}\text { La cuisine de ce restaurant est bon. } \\
\text { (Makanan di restoran ini adalah } \\
\text { sedap) }\end{array}$ & $\begin{array}{l}\text { La cuisine de ce restaurant est } \\
\text { bonne. } \\
\text { (pembetulan kata sifat) }\end{array}$ \\
\hline 11 & $\begin{array}{l}\text { Le chambre est près de la piscine. } \\
\text { (Bilik ini berdekatan dengan kolam } \\
\text { renang). }\end{array}$ & $\begin{array}{l}\text { La chambre est près de la piscine. } \\
\text { (pembetulan artikel) }\end{array}$ \\
\hline 6 & $\begin{array}{l}\text { Marie a passé un très bon journée. } \\
\text { (Mary telah melalui satu hari yang } \\
\text { sangat baik) }\end{array}$ & $\begin{array}{l}\text { Marie a passé une très bonne } \\
\text { journée. } \\
\text { (pembetulan kata sifat \& artikel) }\end{array}$ \\
\hline 17 & $\begin{array}{l}\text { Quels sont vos activités préférés ? } \\
\text { (Apakah aktiviti kesukaan anda?) }\end{array}$ & $\begin{array}{l}\text { Quelles sont vos activités } \\
\text { préférées? } \\
\text { (Pembetulan kata pertanyaan \& } \\
\text { kata sifat) }\end{array}$ \\
\hline 13 & $\begin{array}{l}\text { Vous voulez travailler avec des } \\
\text { personnes étrangers? } \\
\text { (Adakah anda mahu bekerja dengan } \\
\text { warga asing?) }\end{array}$ & $\begin{array}{l}\text { Vous voulez travailler avec } \\
\text { des personnes étrangères? } \\
\text { (pembetulan kata sifat) }\end{array}$ \\
\hline
\end{tabular}


Ayat dalam jadual di atas bertujuan untuk menilai sensitiviti responden terhadap atribusi gender. Jika responden yang tidak melakukan sebarang pembetulan, mereka ini boleh dianggap peka yang ayat tersebut tidak memerlukan pembetulan. Untuk kesemua ayat yang telah diberikan, responden diminta menandakan $(\sqrt{ })$ jika tiada terdapat kesilapan gender gramatikal, dan (X) jika ayat yang diberikan mempunyai kesilapan gender. Responden harus membuat pembetulan yang sesuai di petak yang disediakan dengan menulis ayat yang sepatutnya. Sebagai contoh :

Contoh:

\begin{tabular}{|l|c|c|l|}
\hline & $\sqrt{ }$ & $\mathbf{X}$ & Pembetulan : \\
\hline Elle est un acteur très connu. & & $\mathbf{X}$ & Elle est une actrice très connue. \\
\hline
\end{tabular}

Dari contoh di atas, responden yang mempunyai kepekaan yang penuh akan menjawab:

\section{Elle est une actrice très connue.}

Responden yang tidak peka atau mempunyai kepekaan separa pula mungkin akan menjawab seperti berikut :

Elle est une actrice très connu. $\quad$ Elle est un actrice très connu. atau

Elle est une acteur très connu.

Selanjutnya, pengkaji menggunakan definisi kesilapan pengurangan oleh Dulay, Burt \& Krashen (1982) untuk mengkaji kesilapan tersebut dalam pemerolehan gender gramatikal oleh responden. Kesilapan pengurangan di sini merujuk kepada kesilapan di mana elemen yang penting untuk menghasilkan struktur yang sempurna telah diabaikan.

Sebagai contoh:

La joli femme parle de son chien. (contoh pengkaji sendiri) (Perempuan cantik itu bercakap tentang anjingnya.)

Di sini kesalahan pengurangan yang dilakukan adalah pada kata sifat joli yang merujuk kepada gender subjek yang dinyatakan iaitu la femme. Kata sifat yang sepatutnya digunakan adalah jolie untuk dipadankan dengan subjek la femme tersebut. 
Untuk aktiviti penulisan pula, responden dikehendaki menulis dua karangan yang setiap satunya mempunyai lebih kurang sepuluh (10) ke lima belas (15) ayat. Untuk karangan satu, responden akan menulis tentang aktiviti yang dilakukan oleh seorang lelaki semasa cuti, manakala karangan dua pula menerangkan perihal aktiviti seorang perempuan semasa cuti. Aktiviti penulisan ini bertujuan melihat aplikasi gender gramatikal oleh responden secara terus, iaitu melihat kepekaan semulajadi seseorang responden. Aktiviti penulisan ini pula pada pendapat pengkaji bersifat "terbuka" dan menguji aplikasi unsur tatabahasa ini secara terus.

Para responden diberitahu mengenai apa yang ingin dikaji oleh pengkaji hanya apabila mereka siap menghantar karangan mereka. Tujuan utama pengkaji adalah untuk mengekalkan kepekaan natural (natural awareness) terhadap bahan kajian. Jika mereka diberitahu terlebih dahulu, pengkaji berpendapat yang mereka sudah mempunyai kesedaran tentang apa yang pengkaji inginkan, jadi dapatan pengkaji tidaklah akan menjadi begitu tepat.

Data yang dikumpulkan oleh pengkaji dianalisis secara kuantitatif dan kualitatif, dengan mengenal pasti kesilapan yang dilakukan oleh responden, mengkelaskan kesilapan tersebut dan seterusnya membuat penjelasan tentang kesilapan yang ditemui.

\section{DAPATAN KAJIAN DAN PERBINCANGAN}

Secara keseluruhan, terdapat empat jenis kesilapan pemilihan yang dilakukan oleh para responden iaitu kesilapan ke atas kata sifat, kesilapan ke atas artikel, kesilapan terhadap kata sendi dan kesilapan terhadap kata milik.

\section{Analisis Bahagian Ayat-ayat Bergender Gramatikal}

Dalam bahagian ini, pengkaji ingin menguji kefahaman responden mengenai gender gramatikal, dan sama ada ia dapat diaplikasi secara keseluruhannya atau tidak. Pengkaji juga ingin mengenal pasti strategi yang digunakan dalam pemerolehan gender gramatikal oleh responden.

Daripada kajian yang dilakukan, pengkaji mendapati perincian kesilapan seperti dalam Jadual 3 
Jadual 3

Perincian Kesilapan secara Keseluruhan

\begin{tabular}{lccccccc}
\hline & \multicolumn{2}{c}{$\begin{array}{c}\text { Ayat dengan } \\
\text { pembetulan }\end{array}$} & \multicolumn{2}{c}{$\begin{array}{c}\text { Ayat tanpa } \\
\text { pembetulan }\end{array}$} & \multicolumn{2}{c}{ Jumlah } \\
\cline { 2 - 8 } & $\mathrm{N}$ & $\%$ & $\mathrm{~N}$ & $\%$ & $\mathrm{~N}$ & $\%$ \\
\hline Atribusi tepat & 263 & 44.6 & 467 & 78.62 & 730 & 61.7 \\
Kesilapan penambahan & 23 & 3.90 & 31 & 5.22 & 54 & 4.6 \\
Kesilapan pengurangan & 210 & $\mathbf{3 5 . 5}$ & 38 & $\mathbf{6 . 3 9}$ & 248 & 20.9 \\
Kesilapan pemilihan & 94 & 15.9 & 58 & 9.76 & 152 & 12.8 \\
Jumlah & 590 & $49.83 \%$ & 594 & 50.17 & 1184 & $100 \%$ \\
\hline
\end{tabular}

\section{Analisis Kesilapan Pengurangan Ayat tanpa Pembetulan}

Daripada Jadual 3, didapati kesilapan pengurangan melibatkan $6.39 \%$ daripada keseluruhan kesilapan ayat tanpa pembetulan, di mana responden menilai bahawa kesepuluh ayat yang diberikan di atas mempunyai kesilapan gender tetapi mereka tidak membuat sebarang pembetulan kepada kesilapan yang mereka bayangkan wujud tersebut.

\section{Analisis Kesilapan Aplikasi Gender Ayat dengan Pembetulan}

Bagi ayat dengan pembetulan, pengkaji menggunakan kaedah yang sama iaitu melihat dari segih ketepatan atribusi gender dan kesilapan yang dilakukan. Perincian analisis adalah seperti berikut:

Jadual 4

Frekuensi dan Peratusan Kesilapan bagi Ayat dengan Pembetulan

\begin{tabular}{lccccc}
\hline & No. & \multicolumn{2}{c}{ Kesilapan pengurangan } & \multicolumn{2}{c}{ Jumlah keseluruhan } \\
\cline { 2 - 6 } & & Bil & \% & Bil & \% \\
\hline Ayat Mudah & $\mathbf{1}$ & 10 & 16.6 & & \\
& $\mathbf{3}$ & 28 & 46.7 & & \\
& $\mathbf{4}$ & 25 & 41.7 & & \\
& $\mathbf{1 0}$ & 10 & 16.7 & 134 & \\
& $\mathbf{1 1}$ & 10 & 16.7 & & \\
Ayat & $\mathbf{1 2}$ & 24 & 40.0 & & \\
Kompleks & $\mathbf{1 3}$ & 27 & 45.0 & & \\
& $\mathbf{6}$ & 20 & 33.3 & & \\
\hline
\end{tabular}


Analisis kesilapan pengurangan ini dilihat dari segi kesilapan pengurangan bagi ayat mudah dan kesilapan pengurangan ayat yang mempunyai ciri gender yang kompleks. Ayat mudah dalam kajian ini merujuk kepada ayat yang memerlukan pembetulan mudah, iaitu pembetulan pada artikel kata nama sahaja, sementara ayat kompleks pula merujuk kepada ayat yang memerlukan aplikasi gender yang melibatkan perubahan bentuk. Apa yang dimaksudkan oleh pengkaji tentang perubahan bentuk di sini adalah penukaran yang melibatkan bentuk artikel, kata sifat atau kata sendi, atau kesemuanya sekali dalam satu ayat yang diberikan.

Pengkaji mendapati daripada Jadual 3 kesilapan pengurangan merupakan kesilapan yang paling signifikan (sebanyak 35.5\%) bagi ayat yang memerlukan pembetulan. Bagi ayat mudah (rujuk Jadual 4), kesilapan pengurangan adalah berpunca dari ketidakpekaan responden terhadap pentingnya atribusi gender gramatikal yang menyebabkan responden mengabaikan pembetulan atribusi gender secara langsung. Namun, ia bukanlah satu peratusan yang membimbangkan (63.8\%) jika dibandingkan dengan kesilapan ayat berciri gender gramatikal kompleks yang memerlukan pembetulan dari segi atribusi gender pada artikel kata nama dan kata sifat (36.2\%). Ini adalah kerana kesilapan pada ayat mudah adalah lebih bersifat hafalan sementara kesilapan ayat kompleks pula lebih bersifat aplikasi.

\section{Jadual 5}

Ketepatan Atribusi Gender bagi Ayat Kompleks

\begin{tabular}{ccccccccccc}
\hline $\begin{array}{c}\text { No. } \\
\text { ayat }\end{array}$ & $\begin{array}{c}\text { Tanda } \\
\text { di petak } \\
\text { betul, tiada } \\
\text { pembetulan }\end{array}$ & $\begin{array}{c}\text { Tanda di } \\
\text { petak betul, } \\
\text { pembetulan } \\
\text { salah }\end{array}$ & $\begin{array}{c}\text { Tanda di } \\
\text { petak betul, } \\
\text { pembetulan } \\
\text { separa }\end{array}$ & $\begin{array}{c}\text { Tanda di } \\
\text { petak betul, } \\
\text { keseluruhan } \\
\text { pembetulan } \\
\text { betul }\end{array}$ & $\begin{array}{c}\text { Tanda di } \\
\text { petak salah }\end{array}$ \\
& \multicolumn{1}{c}{ Bil } & \% & Bil & \% & Bil & \% & Bil & \% & Bil & \% \\
\hline 7 & 2 & 3.3 & 7 & 11.7 & 18 & 30 & 10 & 16.7 & 23 & 41.7 \\
6 & 1 & 1.7 & 1 & 1.7 & 15 & 25 & 20 & 33.3 & 23 & 31.7 \\
17 & 4 & 6.7 & 2 & 3.3 & 10 & 16.7 & 10 & 20 & 34 & 53.3 \\
Jumlah & 7 & 3.9 & 10 & 5.6 & 43 & $\mathbf{2 3 . 9}$ & 40 & 38.9 & 80 & 44.4 \\
\hline
\end{tabular}

Kesilapan pengurangan ayat dengan ciri gender gramatikal kompleks ini boleh dibahagikan kepada dua iaitu kesilapan pengurangan menyeluruh dan kesilapan pengurangan separa. Di sini 
pengurangan menyeluruh melibatkan kesilapan pada seluruh ciri gender gramatikal, manakala pengurangan separa pula melibatkan sebahagian ciri gender gramatikal. Daripada 35.5\% responden yang melakukan kesilapan pengurangan (dari Jadual 3), 23.9\% melakukan kesilapan separa (rujuk Jadual 5). Ini bererti hanya 11.6\% daripada keseluruhan responden yang betul-betul tidak peka dengan atribusi gender ini, sementara $23.9 \%$ lagi mempunyai kesedaran tentang peraturan gender gramatikal ini, cuma ianya tidak diaplikasikan secara menyeluruh. Kesilapan pengurangan yang dilakukan adalah seperti berikut :

Jadual 6

Jenis dan Contoh Ayat-Ayat Bergender dengan Kesilapan Pengurangan

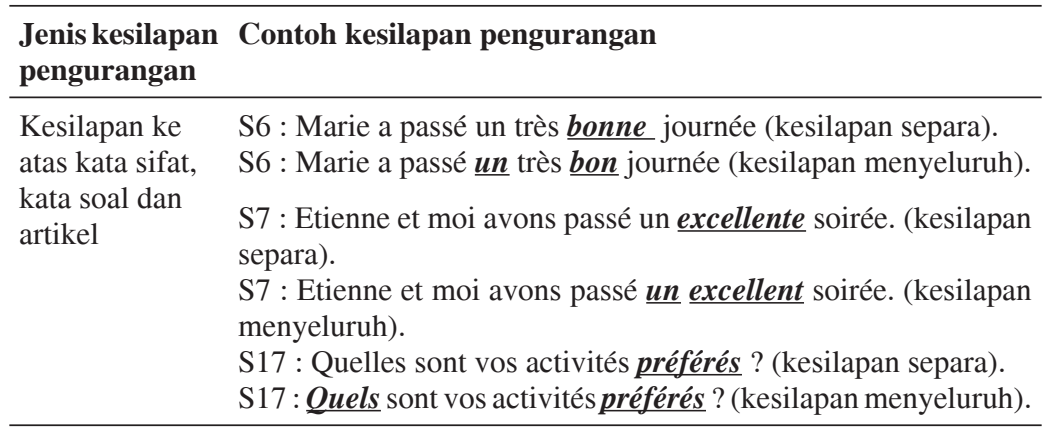

Responden dilihat membuat pembetulan separa sama ada hanya pada kata sifat atau pada kata bilangan, tetapi tidak pada kedua-dua sekali. Ini menampakkan bahawa kesedaran terhadap aplikasi gender wujud dalam kalangan responden tetapi ianya tidak menyeluruh.

\section{Analisis Bahagian Karangan Ringkas}

Secara kasar, sebanyak 800 ayat telah dianalisis yang mewakili 400 ayat daripada karangan 1 dan 400 ayat lagi daripada karangan 2 [anggaran kasar pengkaji berdasarkan pengiraan bilangan minimum ayat untuk dua karangan (20 ayat) didarabkan dengan bilangan pelajar (40 orang)]. Anggaran kasar pengkaji juga mendapati $90 \%$ ayat yang diolahkan dalam karangan adalah ayat dengan ciri gender mudah sementara $10 \%$ lagi merupakan ayat dengan ciri gender gramatikal kompleks. 
Kefahaman gender gramatikal ini dilihat dengan mengambil kira kewujudan artikel, kata sifat dan aplikasi gender dalam partisip lampau. Di sini, analisis dibuat dengan melihat sekali lagi kesilapan yang dilakukan oleh responden, tetapi kali ini ianya merupakan aplikasi terus responden.

\section{Kesilapan Pengurangan ke atas Kata Sifat}

Kesilapan pengurangan ke atas kata sifat adalah seperti berikut:

\begin{tabular}{|c|c|}
\hline $\begin{array}{l}\text { Jenis kesilapan } \\
\text { pengurangan }\end{array}$ & $\begin{array}{l}\text { Kesilapan \& terjemahannya dalam } \\
\text { bahasa Melayu : }\end{array}$ \\
\hline Kesilapan ke atas kata sifat & $\begin{array}{l}\text { J'ai passé de bonne }<>\text { vacances là-bas. } \\
\text { (Saya telah melalui percutian yang baik di sana) }\end{array}$ \\
\hline
\end{tabular}

Bagi kesilapan terhadap kata sifat, ianya merupakan kesilapan separa yang sama, iaitu atribusi gender hanya dilakukan pada kata sifat atau pada artikel, tetapi tidak pada kedua-dua sekali. Ianya juga mungkin berlaku disebabkan kerana responden mengeneralisasikan kata sifat seperti bahasa dominan mereka iaitu bahasa Inggeris, di mana atribusi gender pada kata sifat tidak dalam bentuk jamak.

\section{Kesilapan Pengurangan terhadap Artikel}

Berikut adalah kesilapan pengurangan terhadap artikel oleh responden:

\begin{tabular}{ll}
\hline $\begin{array}{c}\text { Jenis kesilapan } \\
\text { pengurangan }\end{array}$ & \multicolumn{1}{c}{ Kesilapan \& terjemahannya dalam bahasa Melayu : } \\
\hline $\begin{array}{l}\text { Kesilapan } \\
\text { terhadap artikel }\end{array}$ & $\begin{array}{l}\text { Vous avez mangé } \leq>\text { casse-croûte. } \\
\text { (Anda telah makan snek) }\end{array}$ \\
& $\begin{array}{l}\text { Nous avons acheté } \leq>\text { gifts pour notre enfants. } \\
\text { (Kami membeli sedikit buah tangan untuk anak-anak kami) }\end{array}$ \\
& $\begin{array}{l}\text { Kuala Lumpur est } \leq>\text { beau ville. } \\
\text { (Kuala Lumpur adalah satu bandar yang cantik) }\end{array}$ \\
\hline
\end{tabular}

Pengkaji menyifatkan kesilapan pengurangan terhadap artikel adalah berpunca daripada dua faktor. Faktor pertama ialah ketidakpekaan responden secara langsung terhadap atribusi gender membuatkan atribusi yang salah diberikan kepada artikel kata nama. Faktor kedua adalah disebabkan pengaruh bahasa dominan mereka iaitu bahasa 
Inggeris, di mana bagi kata nama jamak, adalah tidak menjadi kesilapan jika artikel digugurkan. Oleh yang demikian, responden mengaplikasikan peraturan yang sama dalam pembentukan ayat dalam bahasa Perancis.

Dalam ayat "we bought presents for our children", tiada artikel diperlukan untuk perkataan presents yang merupakan kata jamak, tetapi dalam bahasa Perancis, artikel adalah sesuatu yang tidak boleh diabaikan. Oleh yang demikian, ayat "nous avons acheté $\leq$ $\geq$ gifts pour notre enfants" harus diberikan artikel des sebelum gifts (cadeau) untuk melengkapkan ayat tersebut.

Perkara yang sama berlaku bagi kata nama dalam bentuk mufrad (singular), iaitu pada ayat "vous avez mangé $\leq>$ casse-croûte" yang dipengaruhi oleh bahasa Melayu (terjemahan: "Anda telah makan $\leq$ $\geq$ snek"). Dalam bahasa Melayu, tiada artikel diperlukan di hadapan kata nama "snek". Justeru itu, responden mengaplikasikan peraturan yang sama dalam bahasa Perancis. Perkara ini didefinisikan Taylors (1975:73-107) sebagai generalisasi melampau iaitu :

"Any error which can be attributed to the application of a rule of English in an inappropriate situation" ...

Pengkaji berpendapat bahawa ianya bukanlah satu kesilapan yang besar yang berpunca daripada ketidakfahaman responden, tetapi lebih menjurus kepada ketidakpekaan responden terhadap atribusi gender gramatikal kepada kata nama yang diberikan.

\section{Kesilapan Pengurangan Terhadap Kata Sendi dan Artikel}

Berikut adalah kesilapan pengurangan terhadap kata sendi dan artikel oleh responden:

\section{Kesilapan \& terjemahannya dalam bahasa Melayu :}

1. Je suis allée à Singapore pendant $\leq>$ dernier vacance. (Saya telah pergi ke Singapura pada cuti yang lepas).

2. Nous sommes rentré $\leq>$ Malaysia. (Kami telah kembali ke Malaysia)

Satu lagi kesilapan pengurangan adalah pada kata sendi menerusi atribusi kata sendi bagi tempat (bangunan, jalan, dan sebagainya). Di sini responden tidak meletakkan kata sendi untuk nama khas 
tempat iaitu nama jalan (seperti Petaling Street), nama bangunan (sebagai contoh $K L C C$ ) dan nama kawasan atau daerah (Petaling Jaya, Ulu Klang, Selangor dan sebagainya). Pengkaji berpendapat bahawa berpunca daripada ketidakpastian responden tentang atribusi yang patut diberikan. Ini diperhatikan daripada kata sendi yang diletakkan pada ayat pertama (à Singapour) yang mempamerkan yang responden sedar kewujudan penggunaan kata sendi, tetapi mengabaikannya dalam ayat kedua kerana dalam ayat tersebut, responden perlu mengetahui gender kata nama (Malaysia) sebelum memberikan atribusi kata sendi yang bersesuaian.

\section{Kesilapan Pengurangan terhadap Artikel Posesif}

Kesilapan pengurangan ini adalah seperti berikut:

\section{Kesilapan \& terjemahannya dalam bahasa Melayu :}

1. J'ai acheté des cadeaux pour mes amis et $\leq>$ famili.

(Saya telah membeli sedikit hadiah untuk kawan-kawan dan keluarga)

2. J'ai acheté des souvenirs pour ma mère et $\leq>$ soeur.

(Saya telah membeli sedikit buah tangan untuk emak dan kakak saya)

Kesilapan pengurangan selanjutnya adalah kesilapan pengurangan bagi kata milik (possessif). Kesilapan ini adalah disebabkan oleh kealpaan responden terhadap peraturan atribusi artikel pada kata nama dan juga oleh pengaruh bahasa dominan dalam pembentukan ayat menggunakan kata milik. Dalam bahasa Perancis, untuk menentukan kata milik, seseorang harus merujuk kepada gender kata nama yang diberikan, sama ada kata nama tersebut adalah bergender maskulin atau feminin, atau dalam bentuk jamak. Untuk menyatakan $\boldsymbol{m y}$ (kepunyaan saya dalam bahasa Melayu), dalam bahasa Perancis seseorang harus merujuk kepada gender kata nama kerana ketigatiga mon, $\boldsymbol{m a}$ atau mes dalam bahasa Perancis membawa maksud my dalam bahasa Inggeris. Dalam bahasa Inggeris, atribusi gender kepada kata milik ini tidak wujud.

Sebagai contoh dalam ayat 'c'est mon appartement' atau 'it's my house' dalam bahasa Inggeris, kata milik mon merujuk kepada kata nama appartement yang bergender maskulin. Dalam ayat 'c'est $\boldsymbol{m a}$ maison' atau 'it's $\boldsymbol{m y}$ house' dalam bahasa Inggeris pula, atribusi gender pada kata milik adalah feminin kerana merujuk kepada maison yang bergender feminin.. 
Pengkaji berpendapat untuk kesilapan pengurangan di sini adalah disebabkan oleh terjemahan dari bahasa dominan yang tidak memerlukan ulangan semula (repetition) kata milik pada kata nama yang dikaitkan pada objek yang sama. Sebagai contoh, dalam ayat "J'ai acheté des souvenirs pour mon mère et $\leq>$ père" misalnya, kesilapan pengurangan kata milik disebabkan di dalam bahasa Inggeris dan bahasa Melayu, kata milik boleh hanya diletakkan di belakang pada kata nama yang terakhir disebut.

Jika dirujuk ayat di atas, dalam bahasa Melayunya, ayat tersebut diterjemahkan kepada "Saya telah membeli sedikit buah tangan untuk emak dan ayah saya". Di sini dapat dilihat bahawa kata milik hanya digunakan sekali sahaja dan diletakkan di belakang kata nama. Dalam bahasa Inggeris pula, jika kita mengambil ayat yang sama dan diterjemahkan, iaitu "I bought some souvenirs for my mother and father", kata milik diletakkan di hadapan kata nama yang pertama dan boleh digugurkan pada kata nama yang kedua.

Hal ini berlainan dengan bahasa Perancis yang memerlukan sama ada artikel, kata milik, varian atau penunjuk dalam bentuk gender gramatikal atau jamak pada setiap kata nama. Oleh sebab itulah, pengaruh bahasa Inggeris dan bahasa Melayu menjadikan responden cenderung untuk membuat kesilapan pengurangan gender gramatikal pada kata milik. Bagi contoh yang diberikan ayat yang sepatutnya diberikan adalah "J'ai acheté des souvenirs pour $\underline{\mathbf{m a}}$ mère et $\underline{\mathbf{m o n}}$ père".

\section{KESIMPULAN DAN CADANGAN}

Kajian ini memberi fokus kepada dua isu penting mengenai pembelajaran gender gramatikal dalam kalangan para pelajar bahasa Perancis tahap dua, iaitu tahap kefahaman dan aplikasi gender gramatikal. Analisis dibuat ke atas kesilapan pembetulan ayat dan dua karangan mudah yang diberikan kepada para pelajar. Data melibatkan 60 responden. Kajian tentang pemahaman dan aplikasi gender gramatikal ini telah menganalisis soalan yang berbentuk pemberian gender yang bersesuaian dan pembetulan ayat yang mempunyai ciri gender gramatikal dari segi kata milik, kata sendi, kata sifat dan artikel.

Dapatan kajian menunjukkan bahawa masalah penggunaan gender gramatikal terjadi apabila para pelajar tidak menyedari betapa 
pentingnya atribusi gender gramatikal pada kata nama, kata sifat dan kata penghubung di dalam bahasa Perancis. Ini menyebabkan para pelajar mengambil mudah tentang atribusi gender tanpa menyedari bahawa perkara tersebut merupakan suatu kesalahan yang besar. Mereka tidak menyedari bahawa kesilapan yang serupa tidak akan dibuat oleh penutur asal dan kesilapan yang dipandang remeh ini adalah suatu kesilapan yang tidak akan dimaafkan oleh penutur asal (Surridge, 1995).

Pengaruh bahasa pertama dan bahasa kedua merupakan satu aspek yang tidak dapat diketepikan dalam pemerolehan bahasa asing, tidak terkecuali pembelajaran gender gramatikal. Towell \& Hawkins (1994:7) mencadangkan bahawa salah satu daripada fenomena yang dapat dilihat dalam pemerolehan bahasa kedua adalah pemindahan unsur tatabahasa B1 kepada tatabahasa B2 pada tahap permulaan pembelajaran.

Hipotesis analisis kontrastif oleh Lado (1957) mencadangkan bahawa para pelajar akan menghadapi masalah apabila bahasa pertama (B1) dan bahasa yang ingin dipelajarinya berbeza. Walau bagaimanapun, jika terdapatnya persamaan antara kedua-dua bahasa, pembelajaran bahasa yang diinginkan akan menjadi lebih mudah. Dalam kajian ini, pengkaji mendapati terdapatnya pengaruh bahasa dominan pelajar, iaitu bahasa Inggeris dan bahasa Melayu di dalam kesilapan pemilihan, kesilapan pengurangan dan kesilapan urutan kata yang dilakukan oleh pelajar.

Jika kita mengkaji kanak-kanak penutur asal bahasa Perancis yang baru belajar bertutur, kita dapat perhatikan yang mereka ini dapat membina sesuatu ayat atau frasa menggunakan gender dengan tahap kesalahan yang sangat minima (Surridge, 1986). Pemerhatian ini sepatutnya menjadi asas kepada pembelajaran pelajar yang mempelajari bahasa Perancis, khususnya berkenaan gender ini. Ianya juga seharusnya menjadi satu persoalan dan sekaligus aspirasi kepada pengajar dalam usaha untuk mengolah masalah pembelajaran gender.

Justeru itu, analisis kesilapan bahasa adalah bertujuan mengkaji kesalahan berkaitan korpus, dan kemudiannya mengenal pasti kesalahan tersebut serta mengkelaskan jenis kesalahan tersebut. Setelah itu, satu analisis terhadap jenis kesalahan dijalankan. 
Dengan cara ini, punca yang menyebabkan kesalahan tersebut dikaji dan hasil dapatan akan digunakan dalam memberikan saranan bagi memperbaiki tahap pengajaran dan pembelajaran serta penggunaan bahasa yang mantap dan betul.

Kajian ini hanya melihat atribusi gender gramatikal daripada aspek yang telah dipelajari oleh pelajar dalam pembelajaran mereka. Kajian ini tidak menyentuh aspek atribusi gender pada aspek tatabahasa yang lebih mendalam seperti ciri-ciri pasif, dan struktur lain yang tidak dipelajari oleh pelajar. Oleh yang demikian, diharapkan kajian yang selanjutnya akan meneroka ini dan disusuli oleh kajian gender gramatikal dalam bahasa asing yang lain seperti bahasa Sepanyol dan bahasa Jerman, supaya dapat dibuat rumusan keseluruhan penggunaan dan kepekaan pelajar dalam atribusi gender gramatikal untuk bahasa asing secara umumnya.

\section{RUJUKAN}

Aini Abdul Karim. (2007). Analisis kontrastif dan analisis kesalahan bahasa: Antara hipotesis dan realiti. Dalam Prosiding Seminar Tahunan Jabatan Bahasa Melayu dan Linguistik (SETALING 2), Brunei.

Clark, E. V. (1985). The acquisition of Romance, with special reference to French. Dalam D. I. Slobin (Ed.), The CrossLinguistic Study of Language Acquisition: Vol. 1. The Data, (hal. 687-782). Hillsdale, NJ: Erlbaum.

Corder, S. P. (1981). Error analysis and interlanguage. London: Oxford University Press.

Corder, S. P. (1967). Error analysis. Dalam J. P. B. Allen dan S. Pit Corder (Eds.), Techniques in Applied Linguistics. London: Oxford University Press.

Dulay, H. C., Burt, M., \& Krashen, S. (1982). Language two. New York: Oxford University Press.

Ellis, R. (1994). The study of second language acquisition. Oxford: Oxford University Press

Fries, C. C. (1945). Teaching and learning English as a foreign language. Ann Arbor: University of Michigan Press.

Hazlina Abdul Halim, Normaliza Abdul Rahim, Mohd Azidan Abdul Jabar \& Adi Yasran Abdul Aziz. (2009). The writing strategy in French language learning among Malaysian 
students: a qualitative approach. International Journal of Learning, 16(5), 445-458.

Hazlina Abdul Halim, Normaliza Abdul Rahim, Mohd Azidan Abdul Jabar \& Adi Yasran Abdul Aziz. (2011a). Grammatical gender misselection and related errors in French writing by Malaysian students. Pertanika Journal of Social Sciences \& Humanities (JSSH), 19(1), 173-181.

Hazlina Abdul Halim \& Mohd Azidan Abdul Jabar (2011c). Kesilapan penambahan dan pengurangan dalam pemerolehan gender gramatikal dalam kalangan pelajar bahasa Perancis. Dalam Hazlina Abdul Halim et al. (Ed.). Lingua 3, hal. 100118. Serdang: UPM Press

James, C. (1998). Errors in language \& use. Harlow : Longman.

Kasper, G., \& Kellerman, E. (1997). Introduction. Dalam Kasper, G. dan Kellerman, E. (Eds.), Communication strategies: Psycholinguistic and sociolinguistic perspectives (hal. 1-13). London: Addison Wesley Longman.

Krashen, S. (1982). Principles and practice in second language acquisition. Oxford: Pergamon.

Kitao, K., \& Kitao, S. K. (2000). Difficulties Japanese have in reading English. Retrieved from http://www.ling.lancs.ac.uk/ staff/visitors/ kenji/kitao/reading.htm

Lado, R. (1957). Linguistics across cultures. Ann Arbor: University of Michigan Press.

Lee, S-H., Jang, S. B., \& Seo, S-K (2009). Annotation of Korean learner corpora for particle error detection. CALICO Journal, 26(3).

Slobin, D. I. (1996). The crosslinguistic study oflanguage acquisition Vol. 2. Hillsdale, NJ: Lawrence Erlbaum Associates.

Sridhar, S. N. (1981). Language teaching and literacy in South Asia. Annual Review of Applied Linguistics, 2, 219-238

Surridge, M. (1996). Le ou la? The gender of French nouns. Clevedon, England: Multilingual matters.

Surridge, M. (1985). Le genre grammatical des composés en français. $C J L(30)$. 247-272.

Surridge, M. (1996) Le ou la ? The gender of French nouns. Clevedon, England: Multilingual matters.

Taylor, B. P. (1975). The use of overgeneralisation and transfer learning strategies by elementary and intermediate students of ESL. Language Learning, 25(1), 73-107 
Towell, R., \& Hawkins, R. (1994). Approaches to SLA. Clevedon: Mulitlingual Matters.

Yarmohammadi, L. (2002). A Contrastive analysis of Persian and English. Payame Noor University Press. 